\title{
The governance of energy transition: lessons from the Nigerian electricity sector
}

\author{
Norbert Edomah* ${ }^{*}$
}

\begin{abstract}
Background: The rising need for transition towards more sustainable energy sources requires a rethink in the governance of energy systems. Arguably, policy makers have very important roles in governing transitions in any given society through established institutional frameworks. It has also been argued that energy infrastructure choices are determined by institutional dynamics and structures. However, what are the underlying influences required to change energy systems and what lessons can we draw from them for the governance of energy transition? This study focuses on understanding the dynamics of energy transition governance in the Nigerian electricity sector with the aim of drawing lessons that impact on energy transition and energy systems change.

Methods: Using explorative research tools, this study investigates the dynamics of energy transition governance in the Nigerian electricity sector with the aim of drawing lessons that impact on energy transition and energy systems change. Data from primary and secondary sources in documentary archives as well as other published sources that are linked with the provision of the Nigerian historical energy infrastructure were used for the analysis in order to draw lessons on energy transition dynamics in Nigeria.

Results: The study revealed that there were three important factors that had a direct impact on energy transition and energy systems change in Nigeria's electricity sector. These are: (1) Changing perceptions and goals (during the period leading up to Nigeria's independence, 1890-1960s); (2) Direct government interventions in energy infrastructure provisions (1940s-1970s); and (3) Major changes in market rules (from 2005 and beyond).

Conclusions: The study concludes by highlighting that: (1) there is a need for government institutions to tackle energy access issues that address the needs of the poor; (2) it is imperative to explore technological options that are more sustainable; and (3) there is a need to address energy consumption patterns that are more energy intensive. Indeed, available energy resources, technological changes in electricity supply systems, and the 'geographies of energy' are major factors that influence energy production and consumption dynamics. All of them needs should be considered, as energy decisions are primarily political choices.
\end{abstract}

Keywords: Energy systems, Fossil fuels, Nigeria, Renewables, Sustainable energy, Sustainability

\section{Background}

Energy systems can be very complex, entangled with multiple interconnected issues that require both urgent and simultaneous solutions that may lead to unprecedented energy transition [1]. Changes necessitating

*Correspondence: nedomah@pau.edu.ng

School of Science and Technology, Pan-Atlantic University, Lagos, Nigeria a transition in energy use have also serious consequences for energy governance [2]. Providing access to modern energy, improving the security of energy supply and reducing the effect of energy systems on climate are three important global energy challenges with implications on national and global energy governance [1]. Energy governance is aimed at addressing some of these challenges. However, the complexity of energy challenges requires the involvement of various original author(s) and the source, provide a link to the Creative Commons licence, and indicate if changes were made. The images or other third party material in this article are included in the article's Creative Commons licence, unless indicated otherwise in a credit line to the material. If material is not included in the article's Creative Commons licence and your intended use is not permitted by statutory regulation or exceeds the permitted use, you will need to obtain permission directly from the copyright holder. To view a copy of this licence, visit http://creativecommons.org/licenses/by/4.0/. The Creative Commons Public Domain Dedication waiver (http://creativeco mmons.org/publicdomain/zero/1.0/) applies to the data made available in this article, unless otherwise stated in a credit line to the data. 
actors and stakeholders in offering solutions that address the diverse aspects of these challenges [3, 4]. Indeed, addressing these challenges requires a polycentric energy governance system as most energy related challenges cannot be easily addressed within a single agency or regime $[5,6]$.

Transitioning away from our current fossil intensive energy system is a necessity [7]. The current state of use of available fossil based resources is simply unsustainable due to the increasing economic, social and environmental requirements. The current technoinstitutional complex discriminates against other technologies and favors fossil fuels [8]. The future of energy is of great concern to both policy makers and end-users alike [9]. It is a considerable central challenge confronting governments, industry players, end users and other stakeholders [10]. Understanding the motives and drivers of energy transitions is of utmost importance in affecting an energy systems change. However, how is energy transition occurring? What lessons can we draw from energy transition dynamics in the global south, within a developing country's context? This paper explores the energy governance dynamics in the Nigerian electricity sector while drawing out lessons on some of the impacts of the various governance dynamics.

Nigeria has been chosen for this study because of its vital role as a major energy provider, as well as its energy poverty challenge [11]. About ninety million people, amounting to about $45 \%$ of Nigerians, have no access to electricity [12-14]. The Nigerian electricity sector has undergone serial changes over time to address some of the inherent challenges, including the partial liberalization of the electricity market. However, some of the problems still persist. In what ways do historical decisions impact on energy transition? What lessons can we draw for future energy governance in the electricity sector in Nigeria and other developing countries with similar trajectories? Addressing these questions within the Nigerian context can provide some generalizable learning that can be used for understanding some historical factors that have shaped the electricity systems in developing countries $[9,15,16]$.

In "Research context" Section, some background is presented that contextualizes the study. "Materials and methods" Section presents some brief methodological considerations. In "Results" Section, the main findings detailing the important features of Nigeria's electricity system and their impact on energy transition are presented. The discussions and concluding thoughts are presented in "Discussion" and "Conclusions" Sections respectively.

\section{Research context}

Energy transition is primarily driven by the quest to reduce environmental harm caused by continuous burning of fossil fuels [15, 17, 18]. A major consequence of this are the efforts directed towards limiting $\mathrm{CO}_{2}$ emissions [19]. Rojey argues that improving energy efficiency, increasing the share of low-carbon energy sources in our energy mix, and introducing Carbon Capture and Storage facilities can help reduce $\mathrm{CO}_{2}$ emissions in a considerable way [20]. Rojey further argues that ensuring technological progress to support new technologies that limit $\mathrm{CO}_{2}$ emissions, defining new energy governance rules that go beyond legislation, and introducing a new lifestyle that are less energy intensive are examples of actions that are required for a successful energy transition.

It is important to understand energy transition from a geographical and political perspective [21-23]. Rocher and Verdeil, in examining the socio-technical collectives involved in the Tunisian energy transition argues that there are four major elements that can be used as a basis to analyze the role of distributed agencies. These elements, which are crucial in understanding the dynamics at play on-the-ground, can help in providing useful guidance on affecting energy transition to low carbon energy sources. They include [21],

- the actors involved in energy issues, including those involved in offering solutions to energy challenges at local, regional and national levels;

- the (shared or unique) visions of the various actors and the goals that they pursue or the interests they defend;

- the current available technologies in the energy production and consumption systems;

- and the conditions and policy instruments under which the current technologies at play are rolled out.

Indeed, at the heart of all the ongoing changes in energy systems are the drivers of electricity demand and supply. It is argued that there are some major drivers of electricity demand and supply necessitating changes in energy systems [24]. These include,

i. Prices: End user energy prices and fuel costs play a vital role in energy systems change. It is generally believed that the higher the energy price, the lower the consumption due to energy efficiency measures, energy savings and/or a switch to other cheaper alternative energy sources would be. Arguably, the life cycle cost of renewables is much cheaper than that of a fossil-based energy source due to additional fuel costs $[25,26]$. 
ii. Economic factors: Factors such as GDP growth rate and increased income levels have a strong correlation with electricity demand growth. Increased income levels of households directly affect comfort levels through increased energy expenditure for cooling and heating requirements [27, 28].

iii. Subsidies: Subsidies for certain types of technologies such as solar PV (and other renewable technologies) play a vital role in ensuring the adoption of such technologies. Subsidies for certain energy resources (such as crude oil and natural gas) also determine to a large extent the kind of energy infrastructure we end up with [29,30].

iv. Structure of electricity demand: This includes demand level, peak load and demand variation, energy intensity, etc. Since electricity cannot be stored, it has to be produced and consumed simultaneously. This means seasonal and instantaneous variations in energy demand have to be met. Indeed, systems need to be matched with the demand in such a way that long term energy demand (over a long time period) and peak load (short term) demand are met [31].

v. Industry structure and other policy factors: Industry structure plays a vital role in energy infrastructure choices. A country/region with intensive industrialization drive will necessarily need to make energy decisions that support industrial growth. Other policy factors such as reaching certain emissions and energy efficiency targets could have significant impact on energy demand and supply [32].

vi. Potential for energy savings and demand side management (DSM): As many countries in Europe are gradually becoming less industrialized and move towards a more service intensive economy, the need for greater energy savings and demand-side management becomes paramount. The offshoring of manufacturing processes necessitates a rethink in energy systems and use, particularly in embracing energy efficiency measures. Technologies that help save and optimize energy consumption could also have significant impact on energy demand [33, 34].

\section{Energy transition dynamics in Nigeria}

Energy transition in Nigeria is a necessity, not only because it provides environmental gains but also because Nigeria's current electricity infrastructure is mainly characterized by an unstable grid, obsolete systems infrastructure, and demanding logistics to keep the lights on $[13,35,36]$. Addressing the challenge of energy infrastructure deficit and replacing obsolete infrastructure provides an opportunity for an energy transition that ensure the provision of more electrical power from cleaner energy sources in a sustainable way without a detrimental impact to the environment [37, 38]. Indeed, if energy transition is a necessity, in what way has Nigeria tried to effect these changes in energy systems? What changes have occurred over time? Fig. 1 provides a panoramic overview of the various stages of the Nigerian energy transition whereas Fig. 2 shows the key features of the Nigerian energy transition within each era of energy use.

In Fig. 1, the various eras of energy use are defined following different time periods. Starting from the preindustrial (agricultural) era from the 1800s, we notice a gradual change in technology use and social practices that became more energy intensive, thus requiring more energy dense sources which explain the changes in energy resource use $[39,40]$. Energy (re)sources have been a major (but not the only) driver and mediator in affecting energy transitions in Nigeria [41]. Changes in energy sources based on available energy resources have also impacted on technology shifts over time [42, 43]. In this study, we further explore the factors that necessitated energy transition and energy systems change within the Nigerian context while particularly focusing on the role of resources and available technologies as is later presented in "Results" Section.

\section{Materials and methods}

This study investigates the dynamics of energy transition governance in the Nigerian electricity sector with the aim of drawing lessons that impacted energy transition and energy system changes. In this study, archival documents of various institutions and other relevant literature were used for data collection by means of documentary literature research tools. Scott argues that documents are texts produced by an individual or a group with the exclusive aim of addressing immediate practical needs [44]. They are written based on particular assumptions and with a clear purpose. In this study, data from primary and secondary sources from documentary archives as well as other published sources associated with the Nigerian historical energy infrastructure provisions were used for analysis in order to get a better understanding of the Nigerian energy (infrastructure) history.

The data were collected from published reports, unpublished internal memos, statistical and historical archives of key institutions that collect records as well as maintain archives of vital historical happenings around the key infrastructure development. The institutional archives visited for the purpose of data collection include,

1. the Nigerian Railway Corporation; 


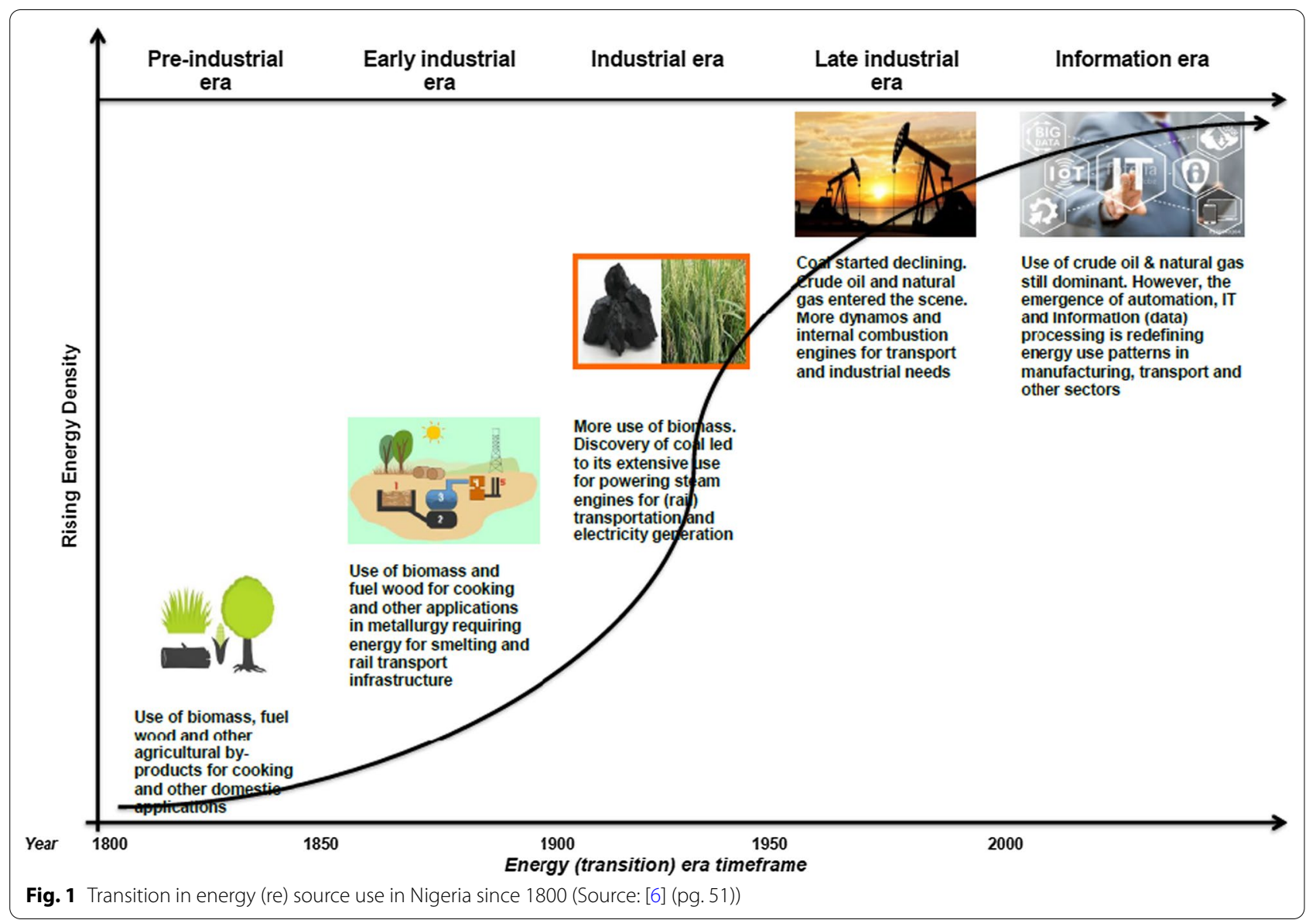

2. the Federal Ministry of Power;

3. Targeted electricity generation companies

4. The Lagos State Records and Archives Bureau

Figure 3 shows the methodological workflow for the study. An analysis of the collected data was carried out using archival analysis. Archival analysis entails sensemaking and drawing meanings from a set of historical texts [45]. The below-mentioned steps were followed in analyzing archival documents/records used in this study $[45,46]$.

1. Vetting the documents: this process involves checking to ascertain if there are any special markings or figures on the documents that could tell us something in connection with the subject under study. Circle or highlight those markings

2. Observing the parts: this entails finding out who wrote the documents and for which purpose. When was the record produced and archived? Are those dates useful in analyzing times of energy transition and how society develops over time?
3. Trying to make sense of the documents: this stage entails trying to obtain the main ideas of the documents. Why was the document written? Are there useful aspects that support my research and might be used as evidence?

4. Use the documents as historical evidence: this stage helps in asking questions that could help provide answers to validate the use of those documents as evidence. For example, where can I find more information about a particular event referenced in the document? Where can I find more information about the person who wrote the document? Are there empirical evidences that are the aftermaths of the issues observed in the documents?

\section{Results}

Following collection and analysis of data, the study reveals that three major factors characterized Nigeria's electricity sector that had a direct impact on Nigeria's energy transition and energy systems change. These are: 


\begin{tabular}{|c|c|c|c|c|c|}
\hline Energy eras & $\begin{array}{c}\text { Pre-industrial } \\
\text { era }\end{array}$ & Early industrial era & Industrial era & Late industrial era & Information era \\
\hline $\begin{array}{l}\text { Energy } \\
\text { resources } \\
\text { (used to satisfy } \\
\text { demand for } \\
\text { energy). }\end{array}$ & \begin{tabular}{|l|} 
Energy \\
requirements \\
from traditional \\
biomass and \\
agricultural \\
products
\end{tabular} & $\begin{array}{l}\text { Energy } \\
\text { requirements from } \\
\text { traditional biomass } \\
\text { and agricultural } \\
\text { products }\end{array}$ & $\begin{array}{l}\text { Energy } \\
\text { requirements from } \\
\text { traditional biomass, } \\
\text { coal, electricity } \\
\text { (particularly coal } \\
\text { fired power plants) } \\
\text { and renewables } \\
\text { (small hydropower) }\end{array}$ & $\begin{array}{l}\text { Energy requirements } \\
\text { from traditional } \\
\text { biomass, electricity } \\
\text { (natural gas and liquid } \\
\text { fuel fired power plants) } \\
\text { and renewables (large } \\
\text { hydropower) }\end{array}$ & $\begin{array}{l}\text { Energy requirements } \\
\text { from traditional } \\
\text { biomass, electricity } \\
\text { (natural gas and } \\
\text { liquid fuel fired power } \\
\text { plants) and } \\
\text { renewables (solar, } \\
\text { wind, small and large } \\
\text { hydropower) }\end{array}$ \\
\hline $\begin{array}{l}\text { Technological } \\
\text { (interventions) } \\
\text { drivers of } \\
\text { energy } \\
\text { infrastructure } \\
\text { supply }\end{array}$ & \begin{tabular}{|l|} 
Agricultural \\
interventions \\
and practices
\end{tabular} & $\begin{array}{l}\text { Metallurgical } \\
\text { interventions }\end{array}$ & $\begin{array}{l}\text { Use of steam } \\
\text { engine for industrial } \\
\text { processes and } \\
\text { electricity } \\
\text { generation }\end{array}$ & $\begin{array}{l}\text { Use of internal } \\
\text { combustion engines } \\
\text { and steam engines for } \\
\text { industrial processes. }\end{array}$ & $\begin{array}{l}\text { Use of data storage } \\
\text { and information } \\
\text { systems infrastructure } \\
\text { for data processing } \\
\text { and storage }\end{array}$ \\
\hline $\begin{array}{l}\text { Commercial } \\
\text { and end-use } \\
\text { drivers of } \\
\text { energy } \\
\text { infrastructure } \\
\text { supply }\end{array}$ & $\begin{array}{l}\text { Trading } \\
\text { activities. Export } \\
\text { of agricultural } \\
\text { produce. Energy } \\
\text { requirement } \\
\text { from manual } \\
\text { labour and draft } \\
\text { animal labour }\end{array}$ & $\begin{array}{l}\text { Trading activities } \\
\text { and export } \\
\text { requirements. } \\
\text { Energy for smelting } \\
\text { activities to produce } \\
\text { agricultural (and } \\
\text { other related) tools }\end{array}$ & $\begin{array}{l}\text { Trading activities. } \\
\text { Energy for industrial } \\
\text { and residential use. } \\
\text { Energy resource } \\
\text { (coal) extraction } \\
\text { and transportation } \\
\text { needs. }\end{array}$ & $\begin{array}{l}\text { Energy for industrial } \\
\text { and residential use. } \\
\text { Energy resource (crude } \\
\text { oil and natural gas) } \\
\text { extraction and } \\
\text { production. Energy } \\
\text { needs for mass and } \\
\text { individualized } \\
\text { transportation. }\end{array}$ & $\begin{array}{l}\text { Energy requirements } \\
\text { for industrial, } \\
\text { manufacturing and } \\
\text { automated } \\
\text { processes. Data } \\
\text { storage requirements } \\
\text { and increased energy } \\
\text { demand for transport. }\end{array}$ \\
\hline $\begin{array}{l}\text { Institutional } \\
\text { frameworks for } \\
\text { energy } \\
\text { (electricity) } \\
\text { policy } \\
\text { implementation }\end{array}$ & \begin{tabular}{|l|} 
Decisions \\
targeted at \\
addressing their \\
basic needs by \\
families and \\
community \\
groups
\end{tabular} & $\begin{array}{l}\text { Traditional rulers } \\
\text { and the British } \\
\text { colonial institutions, } \\
\text { such as the Public } \\
\text { Works Department } \\
\text { (PWD), and the } \\
\text { Nigerian Railway } \\
\text { Corporation (NRC) }\end{array}$ & $\begin{array}{l}\text { British colonial } \\
\text { institutions, such as } \\
\text { the Public Works } \\
\text { Department(PWD) } \\
\text { and the Nigerian } \\
\text { Electricity Supply } \\
\text { Company (NESCO) } \\
\text { established in 1922) }\end{array}$ & $\begin{array}{l}\text { Niger Dams Authority } \\
\text { (NDA - est.1962). } \\
\text { National Electric Power } \\
\text { Authority (NEPA - est. } \\
\text { 1972). Electricity } \\
\text { Commission of Nigeria } \\
\text { (ECN - est. 1973), etc, } \\
\text { were important } \\
\text { institutional actors }\end{array}$ & $\begin{array}{l}\text { Power Holding } \\
\text { Company of Nigeria } \\
\text { (PHCN - est. 2005), } \\
\text { Nigerian Electricity } \\
\text { Regulatory } \\
\text { Commission (NERC- } \\
\text { est. 2007), etc. are } \\
\text { important institutional } \\
\text { actors }\end{array}$ \\
\hline
\end{tabular}

Fig. 2 A panoramic view of the energy eras and the key features of the Nigerian energy transitions [18]

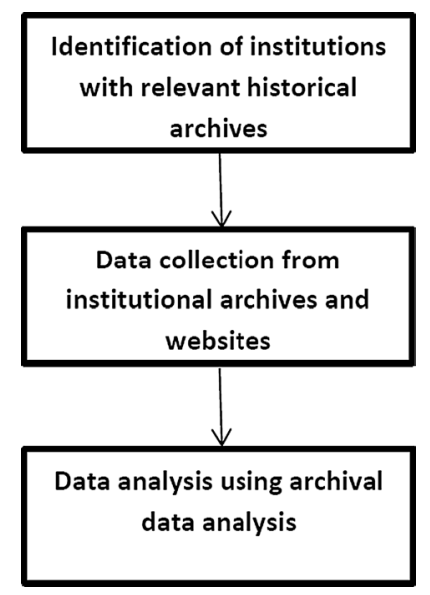

Fig. 3 Methodological workflow

- changing perceptions and goals (during the period leading up to Nigeria's independence, 1890-1960s);

- direct government interventions (1940s-1970s);

- major changes in market rules (from 2005 and beyond)
The following sub-sections now delve into further details around the aforementioned themes.

\section{Changing perception and goals of Nigeria's electricity system (1890-1960s)}

The study revealed that changing perception and goals of Nigeria's electricity systems were manifested in three main ways:

- The change in motives for energy infrastructure provision

- Intermittent switch in energy fuels

- Changes in energy technology in use

With respect to the change in the motives for energy infrastructure provisions, the study revealed that initial provision of electricity infrastructure was motivated by the need to light up settlements and government offices mostly occupied by Europeans. Lighting was the primary motive for the provision of the first power plant in Nigeria, the Lagos Marina station as shown in Table 1. The increased demand for electricity beyond lighting applications led to the expansion of existing plants and the provision of new ones as shown in Table 1. The need to power the workshops of the Nigerian Railway 
Table 1 Summary of electricity infrastructure provision in colonial Nigeria ( Source: Author compilation)

\begin{tabular}{|c|c|c|c|c|c|c|c|}
\hline$s / n$ & $\begin{array}{l}\text { Power station/ } \\
\text { supply }\end{array}$ & Year & Capacity & Fuel type & Technology type & Main application & End-user group \\
\hline 1 & Lagos Marina Station & 1896-1920 & $\begin{array}{l}30 \mathrm{KW} \text { which grew to } \\
420 \mathrm{KW}\end{array}$ & Diesel & Steam engines & Lighting application & Mainly Europeans \\
\hline 2 & Iddo Power Station & 1923 & $\begin{array}{l}\text { 3.6 MW which grew } \\
\text { to } 13.75 \mathrm{MW}\end{array}$ & Coal & $\begin{array}{l}\text { Coal-fired steam } \\
\text { engines }\end{array}$ & $\begin{array}{l}\text { Lighting and Railway } \\
\text { workshops }\end{array}$ & Mainly Europeans \\
\hline 3 & $\begin{array}{l}\text { Plateau Electricity } \\
\text { Supply (owned by } \\
\text { the Nigeria Electricity } \\
\text { Supply Company- } \\
\text { NESCO_a British } \\
\text { company }\end{array}$ & 1922-1945 & $\begin{array}{l}2 \mathrm{MW} \text { which grew } \\
\text { to } 12 \mathrm{MW} \text { (with peak } \\
\text { load at installed } \\
\text { capacity of } 18.4 \mathrm{MW} \text { ) }\end{array}$ & Hydro & Hydro-electric plant & $\begin{array}{l}\text { Lighting applications } \\
\text { and mining industry }\end{array}$ & $\begin{array}{l}\text { European settlements } \\
\text { and Tin mines }\end{array}$ \\
\hline 4 & $\begin{array}{l}\text { Enugu Electricity } \\
\text { Supply }\end{array}$ & 1922-1953 & $\begin{array}{l}3 \times 350 \mathrm{KW} \text { plant } \\
\text { which grew to } \\
3000 \mathrm{KW} \text { by } 1953\end{array}$ & Diesel & Steam engine plants & Lighting and industry & $\begin{array}{l}\text { Nigerian Eastern Rail- } \\
\text { way (NER) workshops, } \\
\text { European settlements, } \\
\text { Church, and Barack }\end{array}$ \\
\hline 5 & $\begin{array}{l}\text { Nigerian Railway Plant } \\
\text { Port-Harcourt }\end{array}$ & 1928 & $\begin{array}{l}2250 \mathrm{KW} \text { that grew up } \\
\text { to } 8530 \mathrm{KW}\end{array}$ & Diesel & Steam engines & $\begin{array}{l}\text { Industrial application } \\
\text { (transport) }\end{array}$ & $\begin{array}{l}\text { Nigerian Railway } \\
\text { Corporation (NRC) } \\
\text { workshops }\end{array}$ \\
\hline 6 & $\begin{array}{l}\text { Kaduna Northern } \\
\text { Province Head } \\
\text { Quarters }\end{array}$ & 1929 & $\begin{array}{l}8.28 \mathrm{MW} \text { installed } \\
\text { capacity }\end{array}$ & Diesel & Steam engines & $\begin{array}{l}\text { Lighting, residential } \\
\text { and administrative } \\
\text { uses }\end{array}$ & $\begin{array}{l}\text { Government offices } \\
\text { and residential areas }\end{array}$ \\
\hline
\end{tabular}

Corporation (NRC) for the maintenance of locomotives triggered the next wave of power plant expansion. In the Plateau region of Nigeria, the need to provide electricity to support mining activities for Tin was another motivation for provision of electricity infrastructure in that region. The topography of the region (being a high plateau) supported the provision of the first hydropower plant in Nigeria. Indeed, lighting, powering of NRC workshops, supporting the Tin mines and powering government offices and government settlements were key motives for the provision of electricity infrastructure in pre-independent Nigeria.

The fuel source for the power plants also constituted a vital part of electricity infrastructure decisions. The study revealed that during colonial Nigeria, most power plants depended on diesel as their fuel source which at that time was imported from the United Kingdom. However, the discovery of coal in Nigeria in 1909 triggered the use of coal for the Iddo power station that was commissioned in 1923. Indeed, the study further revealed that the discovery of coal did not really change the energy fuel trajectory from diesel to coal. However, it was observed that more diesel power plants were installed up to 1940 as shown in Table 2.

Energy technology also played a dominant role in the provision of electricity infrastructure in Nigeria. The study revealed that the dominant technology for most power plants that were deployed in Nigeria between 1890 and 1940 were steam engine technologies that
Table 2 Other electrical infrastructure provision in Nigeria (1933-1940) (Source: Author compilation)

\begin{tabular}{lllcl}
\hline s/n & Location & Institution Responsible & Year & Capacity (KW) \\
\hline 1 & Katsina & Native Authority & 1933 & 100 \\
2 & Maiduguri & $\begin{array}{l}\text { Public Works Department } \\
\text { (PWD) }\end{array}$ & 1934 & 210 \\
3 & Abeokuta & Native Authority & 1935 & 600 \\
4 & Yola & $\begin{array}{l}\text { Public Works Department } \\
\text { (PWD) }\end{array}$ & 1937 & 75 \\
5 & Zaria & $\begin{array}{l}\text { Public Works Department } \\
\text { (PWD) }\end{array}$ & 1938 & 1436 \\
6 & Calabar & $\begin{array}{l}\text { Public Works Department } \\
\text { (PWD) }\end{array}$ & 1939 & 570 \\
7 & Warri & $\begin{array}{l}\text { Public Works Department } \\
\text { (PWD) }\end{array}$ & 1939 & 530 \\
8 & Ibadan & Native Authority & 1940 & 4515 \\
\hline
\end{tabular}

were either diesel-fired of coal-fired power plants. The only exception was the hydropower plant built in the plateau region due to the advantages presented by the topography of the region. Indeed, the study demonstrated that there was a case of technological lock-in to the use of steam engine technologies that was interrupted (and completely halted) by the Second World War since at that time it became impossible to get maintenance spares for the plants owing to the war.

Some other power stations that operated on stream are listed in Table 2, along with their capacity, location and institution responsible for its provision. 


\section{Direct government interventions (1940s-1970s)}

The study reveals that government intervention in the provision of electricity infrastructure was evident through the establishment of institutions that were given the mandate to address a specific challenge that served as a barrier to the diffusion, spread and expansion of a new and existing electricity infrastructure catering to the growing energy needs. Table 3 provides a summary of various government interventions in electricity infrastructure, institutions responsible and their central focus.

In the 1940s, the Nigerian Government Electricity Undertaking (NGEU) was established by the British colonial government out of the Public Works Department (PWD) to design a plan to increase electricity infrastructure provision by at least $200 \%$ to pave the way for industrialization in Nigeria. This intervention led to the establishment of several industries in different parts of the country starting from the early 1950s. Indeed, by 1970, there were more than 2000 industries scattered around different industrial estates in Nigeria. The NGEU, which was set up as a holding company, eventually morphed into a new corporation in the 1950s called the Electricity Corporation of Nigeria.

The Electricity Corporation of Nigeria (ECN) was the second major institutional intervention set up by the Nigerian government with a mandate of seeking ways of providing the cheapest form of energy that is consistent with continuity of supply. The ECN was established on the $6^{\text {th }}$ of July 1950 but only took over from the NGEU on the 1st of April 1951. The ECN continued with their established mandate. However, frequent cases of fire outbreaks owing to electrical faults necessitated an intervention by the Nigerian government to further extend the mandate given to the ECN (in the 1960s) to include developing standards for electrical equipment and devices to help curtail the frequent fire incidences.

The study further revealed that in the 1960s, government interventions on electricity infrastructure provision led to the establishment of the Niger Dams Authority (NDA) with a clear mandate of developing Nigeria's hydropower potential. This intervention led to the planning and provision of several large dams in Nigeria, particularly Kainji, Jebba and Shiroro dams.

The need to have a coordinated system where one central institution of government can take charge and responsibility for everything that has to do with electricity infrastructure in Nigeria led to the establishment of the National Electric Power Authority (NEPA) in the 1970s. NEPA came about as the result of a merger of the Niger Dams Authority and the Electricity Corporation of Nigeria.

Indeed, the study further revealed that there were other interventions that were mainly private interests. The Nigerian Electricity Supply Company (NESCO), a British company, and the African Timber and Plywood Company (AT\&P) are examples. Table 4 shows the number of power station $\mathrm{s}$ in Nigeria as of 1952 and the institutions responsible for its provision.

The study also demonstrated that several government interventions led to widespread diffusion and provision of several electricity infrastructures. As of 1953/54, there were a total of 43,659 electricity consumers in Nigeria. With respect to the electricity consumption patterns in the 1953/54 fiscal year, about $50.3 \%$ of electricity produced was consumed through various forms of domestic

\begin{tabular}{|c|c|c|c|}
\hline$s / n$ & Responsible institutions & $\begin{array}{l}\text { Number } \\
\text { of power } \\
\text { plants }\end{array}$ & $\begin{array}{l}\text { Power generated } \\
\text { (in million } \mathrm{KW} \text { ) }\end{array}$ \\
\hline 1 & ECN & 17 & 89.1 \\
\hline 2 & NESCO & 1 & 66.6 \\
\hline 3 & AT\&P & 1 & \\
\hline 4 & $\begin{array}{l}\text { Planned and under construc- } \\
\text { tion }\end{array}$ & 17 & \\
\hline \multirow[t]{2}{*}{5} & Industrial undertakings & & 9.5 \\
\hline & TOTAL & & 165.2 \\
\hline
\end{tabular}

Table 3 Direct government interventions in Nigeria's electricity infrastructure provision ( Source: Author compilation)

\begin{tabular}{|c|c|c|c|}
\hline $\mathbf{s} / \mathbf{n}$ & Year & Institution & Main mandate/focus \\
\hline 1 & $1940 \mathrm{~s}$ & Nigerian Government Electricity Undertaking (NGEU) & $\begin{array}{l}\text { Design a plan to increase the electricity generation capacity by at least } 200 \% \text { to } \\
\text { support industrialization }\end{array}$ \\
\hline 2 & $1950 \mathrm{~s}$ & Electricity Corporation of Nigeria (ECN) & Provide the cheapest form of energy consistent with continuity of supply \\
\hline 3 & $1960 \mathrm{~s}$ & Electricity Corporation of Nigeria (ECN) & $\begin{array}{l}\text { Address issues and concerns about electrical standards due to repeated fires in } \\
\text { Lagos caused by electrical faults }\end{array}$ \\
\hline 4 & $1960 \mathrm{~s}$ & Niger Dams Authority (NDA) & Develop Nigeria's hydropower potential \\
\hline 5 & $1970 \mathrm{~s}$ & National Electric Power Authority (NEPA) & $\begin{array}{l}\text { Take charge of provision, operation and maintenance of electricity infrastructure } \\
\text { nationwide }\end{array}$ \\
\hline
\end{tabular}


applications, closely followed by power requirements for public utilities which took about $33.1 \%$. Commercial applications were responsible for $12.7 \%$ of total electricity consumption while public lighting and other miscellaneous uses accounted for 1.7 and $2.2 \%$, respectively, of total electricity consumption as shown in Fig. 4.

\section{Major changes in market rules (from 2005 and beyond)}

The study revealed that major changes in market rules played an important role in the governance of energy transition in Nigeria. Some key events highlighted in Table 5 led to changes in market rules in Nigeria's electricity sector and also affected Nigeria's energy transition.

The liberalization of the Nigerian electricity sector was a major reason for changes in market rules. This process started in 2001 with the introduction of the National Electric Power Policy (NEPP) which paved

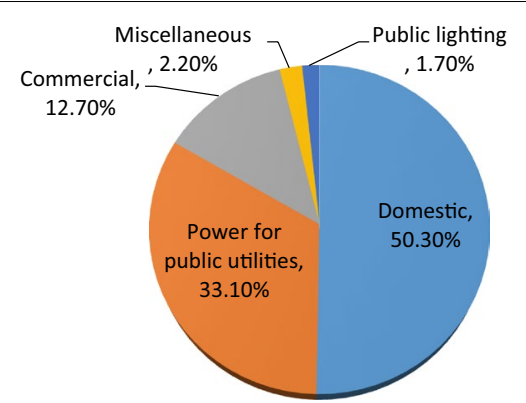

Fig. 4 Electricity consumption pattern in Nigeria (1953/54) the way for the production of the National Energy Policy (NEP) framework in 2003. The NEP framework provided a basis for the preparation and enactment of the Electrical Power Sector Reforms Act (EPSRA) in 2005. The EPSRA act provided the legal/regulatory backing that aided the liberalization process of the Nigerian electricity sector. This act paved the way for the establishment of the Power Holding Company of Nigeria (PHCN), a holding company that was eventually unbundled to eighteen companies comprising six generation companies, one transmission company and eleven distribution companies.

The study indicated that the liberalization of the Nigerian electricity market also opened up other opportunities for Nigeria by providing a platform for the establishment of some important agencies of the government or some regulations to address specific challenges within the Nigerian power sector. An example is the formation of the Nigerian Electricity Regulatory Commission (NERC) saddled with the responsibility of regulating the activities of various players within the Nigerian electricity sector. The Renewable Energy Policy Guideline (REPG) and the Renewable Action Program (REAP) were instrumental for initiating the large-scale deployment of solar home systems and offgrid solutions. The national biofuels policy formulated in 2007 assisted the formulation of a national guideline for the use of biofuels. Indeed, these various changes in market rules were instrumental in the liberalization of the Nigerian electricity market which paved the way

Table 5 Key events leading to changes in market rules in Nigeria's electricity sector (2000-2015) ( Source: Adapted from [47])

\begin{tabular}{|c|c|c|}
\hline $\mathbf{s} / \mathbf{n}$ & Year & Events impacting market rules \\
\hline 1 & 2001 & National Electric Power Policy (NEPP) initiated \\
\hline 2 & 2003 & National Energy Policy (NEP) framework produced \\
\hline 3 & 2004 & National Economic Empowerment and Development Strategies (NEEDS) issues to address development challenges (including energy) \\
\hline 4 & 2005 & Electric Power Sector Reform Act (EPSRA) enacted \\
\hline 5 & 2005-07 & $\begin{array}{l}\text { Formation of the Nigerian Electricity Regulatory Commission (NERC); } \\
\text { The formation of the Power Holding Company of Nigeria (PHCN); and the eventual unbundling of the PHCN into } 18 \text { companies }\end{array}$ \\
\hline 6 & 2006 & Renewable Energy Policy Guideline (REPG) was released, together with the Renewable Energy Action Program (REAP) \\
\hline 7 & 2007 & National Biofuels Policy and incentives were formulated \\
\hline 8 & 2008-09 & Multi-Year Tariff Order (MYTO) was established while the Power Sector Reforms Committee was established \\
\hline 9 & 2010 & $\begin{array}{l}\text { The Presidential Task Force on Power (PTFP) and the Presidential Action Committee on Power (PACP) were established } \\
\text { The Power Sector Roadmap was released }\end{array}$ \\
\hline 10 & 2012 & MYTO 2 was approved and released \\
\hline 11 & 2013 & $\begin{array}{l}\text { Privatization of generation and distribution companies was initiated. Transmission was retained by the government but managed } \\
\text { under a management contract agreement (by Manitoba Hydro International-MHI) }\end{array}$ \\
\hline 12 & 2015 & $\begin{array}{l}\text { Commencement of the Transitional Electricity Market (YEM) regime } \\
\text { Tenure of the NERC Commissioner ended (Dec) } \\
\text { MYTO } 2.1 \text { approved and released but faced opposition from consumer groups (with a proposed 80\% price increase which was later } \\
\text { reduced by } 25 \% \\
\text { Draft Rural Electrification Strategy \& Plan (RESP) was released. The National Renewable Energy \& Energy Efficiency Policy (NREEEP) was } \\
\text { also released }\end{array}$ \\
\hline
\end{tabular}


for the inclusion of cleaner on-grid and off-grid energy sources to Nigeria's energy mix.

\section{Discussion}

Following the findings from this study, four important lessons can be drawn from the Nigerian case for the understanding of energy transition processes in developing African countries. These processes include;

1. policy and institutional interventions shaping energy transition pathways;

2. technological interventions tending towards technological lock-in

3. societal everyday practices shaping energy use patterns

4. available energy resources playing a major role in energy technology choices

Following these findings, it is evident that policy and institutional interventions manifest themselves in various ways, particularly through government institutions and other multilateral organizations that come together to seek ways of addressing some common societal and global challenges such as energy access [48, 49], energy security $[43,50]$, de-carbonization $[51,52]$ and climate change issues [53,54]. We noticed similar trajectories of policy and institutional interventions (as in Nigeria) in Ghana that led to the initial provision of diesel-fired generators, hydro power plants and later large gas-fired thermal power plants [55]. These interventions were driven by both endogenous and exogenous factors such as increased residential energy demand, energy for industrialization and commerce, and later, climate change agreements [56-58].

Another important factor in the policy environment that impacted on the electricity infrastructure interventions in Nigeria was an industrial policy (from the 1940s) aimed at providing the electricity infrastructure to aid industrialization $[6,59]$. This greatly shaped electricity planning that led to increased coal -fired power plants in the 1940s, and later the building of hydro-power plants from the 1950s. The provision of thermal power plants and (more recently) the scaling up of decentralized renewables as a way to address energy access issues and to support small businesses are also results of policy interventions [60]. The World Bank Group argues that to achieve a sustainable energy future for all, there is a need to ensure universal energy access that focuses on the poor which can be achieved more quickly through the rapid expansion of renewable energy [61]. Indeed, exploring the political economy of energy is important in order to understand energy transition processes $[7,62,63]$.
Various technological interventions over time have impacted on energy systems change and energy transition. Electricity systems in many countries started off with the use of steam engines from the late 1800s to the early 1900s [41]. Further technological changes that saw the shift from one technology to another also occurred. The shift from steam engines [64] to diesel engines [65], thermal power plants [66], hydroelectric power [67] and the various forms of renewable technologies, including solar photovoltaic cells [68], concentrated solar plants [69], wind technology [70], etc., are clear evidence of the role of various energy technology pathways in ensuring energy transition and energy system changes within the Nigerian context.

Social and societal (everyday) practices, which essentially consist of the way people habitually do things, have evolved over time [71]. Some everyday practices such as cooking, commuting, trading, entertaining, etc., have evolved over time in such a way that they now require more energy than ever before [72-74]. The fact that energy infrastructure provision has enabled some everyday practices to be performed in a manner that helps to satisfy the need for greater levels of comfort, cleanliness and convenience has also increased the public value for energy $[28,75]$. Indeed, energy is that net currency that enables the actualization and entrenchment of new and existing practices becoming more energy intensive.

Available energy resource options have played (and will continue to play) a dominant role in energy choices and energy system changes. Most countries started off with electricity systems that depended on coal as the major fuel source. The discovery of other fuels such as crude oil and natural gas changed the energy landscape by enabling the introduction and provision of new power plants that depended on those fuel sources [76].

Political interests of policy makers also came to play a major role in many infrastructure decisions, particularly energy and electricity. Prior to 1960, many infrastructure decisions were aligned to the interest of the colonial governments. Between 1966 and 2000, Nigeria was under (the most part of the period) a military rule. Most decisions were results of military edicts with minimal stakeholder consultation $[6,18]$. This meant that a lot of the infrastructure provided during this era was simply aligned to the interest of the military regime. From the 2000 s, with the advent of a democratic rule, there was a gradual transition to infrastructure decision making that had a pattern of inclusiveness that was aligned to the interests of policy makers $[41,43]$.

A major limitation of this study is the sole dependence on archival records for data collection and analysis. Archival analysis was necessary since those who were involved in most historical electricity infrastructure 
decisions prior to 1960 are either dead or were unavailable to be interviewed in order to understand the historical energy transition governance dynamics. Indeed, interviewing stakeholders who were involved in historical electricity infrastructure decisions prior to Nigeria's independence (in 1960) would have provided more insights in the transition factors (such as contextual factors and future expectations) that led to certain transition outcomes in the forms of changes in energy systems [43, 77].

\section{Conclusions}

To conclude, there are three takeaways from this study that are of utmost importance. First, there is a need for government institutions to tackle energy access issues that addresses the needs of the poor; Secondly, it is imperative to explore technological options that are more sustainable; and thirdly, there is a need to address energy consumption patterns that are more energy intensive. Indeed, available energy resources, technological changes in electricity supply systems, and the 'geographies of energy' are major factors that influence energy production and consumption dynamics. All of them needs to be considered as energy decisions are primarily political choices.

\begin{abstract}
Abbreviations
AT\&P: African Timber and Plywood Company; ECN: Electricity Corporation of Nigeria; NRC: Nigerian Railway Corporation; NGEU: Nigerian Government Electricity Undertaking; NDA: Niger Dams Authority; NEPA: National Electric Power Authority; NESCO: Nigerian Electricity Supply Company; NERC: Nigerian Electricity Regulatory Commission; MYTO: Multi-Year Tariff Order; PHCN: Power Holding Company of Nigeria.
\end{abstract}

\section{Acknowledgements}

The author expresses their profound gratitude to the Nigerian Railway Corporation for permission to access their archives used in this research.

\section{Authors' contributions}

This work is solely authored by the corresponding author. All authors read and approved the final manuscript.

\section{Funding}

This research did not receive any funding from any institution. However, we would like to express sincere thanks to the Merian Institute for Advanced Studies in Africa (MIASA) for agreeing to fund the APC charges for this research in the Special issue on "The Governance of Energy Transition in the Global South".

\section{Availability of data and materials}

All data used for this study are embedded in the manuscript. Other materials can be provided on request.

\section{Declarations}

Ethics approval and consent to participate Not applicable.

\section{Consent for publication}

Not applicable.

\section{Competing interests}

The authors declare that they have no competing interest.

Received: 24 February 2021 Accepted: 22 October 2021

Published online: 02 November 2021

\section{References}

1. Cherp A, Jewell J, Goldthau A (2011) Governing global energy: systems, transitions, complexity. Glob Policy 2:75-88. https://doi.org/10.1111/j. 1758-5899.2010.00059.x

2. Lange M, O'Hagan AM, Devoy RRN et al (2018) Governance barriers to sustainable energy transitions-Assessing Ireland's capacity towards marine energy futures. Energy Policy 113:623-632. https://doi.org/10. 1016/j.enpol.2017.11.020

3. Hettinga S, Nijkamp P, Scholten H (2018) A multi-stakeholder decision support system for local neighbourhood energy planning. Energy Policy 116:277-288. https://doi.org/10.1016/j.enpol.2018.02.015

4. Edomah N, Foulds C, Jones A (2016) The role of policy makers and institutions in the energy sector: the case of energy infrastructure governance in Nigeria. Sustainability 8:829. https://doi.org/10.3390/su8080829

5. Goldthau A (2014) Rethinking the governance of energy infrastructure: scale, decentralization and polycentrism. Energy Res Soc Sci 1:134-140. https://doi.org/10.1016/j.erss.2014.02.009

6. Edomah N (2020) Electricity and Energy Transition in Nigeria, 1st ed. doi: https://doi.org/10.4324/9780367201456

7. Sovacool BK (2017) The History and Politics of Energy Transitions. In: The Political Economy of Clean Energy Transitions. United Kingdom: Oxford University Press, pp 1-25

8. Aklin M, Urpelainen J (2013) Political competition, path dependence, and the strategy of sustainable energy transitions. Am J Pol Sci 57:643-658. https://doi.org/10.1111/ajps

9. World Economic Forum (2013) Energy transitions: Past and Future. World Economic Forum, Geneva Switzerland

10. Amin A (2017) Drivers, challenges and opportunities of the global sustainable energy transition-developments in the MENA region and Jordan. Available: www.irena.org. Accessed 14 Sept 2018

11. Gwénaëlle Legros, Havet I, Bruce N, Bonjour S (2009) The energy access situation in developing countries: a Review focusing on the least developed countries and Sub-Saharan Africa. United Nations Development Programme (UNDP) and World Health Organization (WHO). New York, USA. Available: http://content.undp.org/go/cms-service/stream/asset/? asset_id=2205620

12. REA (2017) PROJECT STATUS_Total completed projects in 2017. In: Rural Electrif. Agency. https://rea.gov.ng/projectstatus/. Accessed 26 May 2020

13. Ugwoke B, Gershon $O$, Becchio C et al (2020) A review of Nigerian energy access studies: the story told so far. Renew Sustain Energy Rev 120:109646. https://doi.org/10.1016/J.RSER.2019.109646

14. Dioha MO, Kumar A (2020) Exploring the energy system impacts of Nigeria's Nationally Determined Contributions and low-carbon transition to mid-century. Energy Policy 144:111703. https://doi.org/10.1016/j.enpol. 2020.111703

15. Edomah N, Bazilian M, Sovacool B (2020) Sociotechnical typologies for national energy transitions. Environ Res Lett 15:111001. https://doi.org/ 10.1088/1748-9326/abba54Manuscript

16. Griffith-Jones S, Antonio Ocampo J, Spratt S (2011) Development financing renewable energy in developing countries : mechanisms and responsibilities. Eur Rep.

17. Davidsson S (2014) Global Energy Transitions. WeltenergieratDeutschland e. V./Gertraudenstraße 20/D-10178 Berlin

18. Edomah N (2018) Historical drivers of energy infrastructure change in Nigeria (1800-2015). In: Gokten S (ed) Energy management for sustainable development. InTechOpen, London, pp 23-45

19. Ogland-Hand JD, Bielicki JM, Buscheck TA (2017) The value of CO2-bulk energy storage to reducing CO2 emissions. Energy Proc 114:6886-6892. https://doi.org/10.1016/j.egypro.2017.03.1830

20. Rojey A (2009) Energy \& climate: how to achieve a successful energy transition, 1st edn. John Wiley Sons Ltd., Chichester

21. Rocher L, Verdeil É (2013) Energy transition and revolution in Tunisia: politics and spatiality. Arab World Geogr 16:267-288 
22. Bridge G, Bouzarovski S, Bradshaw M, Eyre N (2013) Geographies of energy transition: Space, place and the low-carbon economy. Energy Policy 53:331-340. https://doi.org/10.1016/j.enpol.2012.10.066

23. Frantál B, Pasqualetti MJ, Van der Horst D (2014) New trends and challenges for energy geographies: introduction to the special issue. Morav Geogr Rep 22:6-10. https://doi.org/10.2478/mgr-2014-0006

24. Observatoire Méditerranéen de l'Energie (2007) The Drivers of Electricity Demand and Supply. Fondazione Eni Enrico Mattei (FEEM), Milan, Italy

25. REN21 (2019) Renewbles 2019 global status report. REN21 Secretariat, Paris

26. IRENA (2019) Renewable power generation costs in 2018. International Renewable Energy Agency, Abu Dhabi

27. Grandclément C, Karvonen A, Guy S (2014) Negotiating comfort in low energy housing: the politics of intermediation. Energy Policy 84:213-222. https://doi.org/10.1016/j.enpol.2014.11.034

28. Shove E (2003) Converging conventions of comfort, cleanliness and convenience. J Consum Policy. https://doi.org/10.1023/A:1026362829781

29. World Bank (2010) Subsidies in the Energy Sector: An Overview. Background Paper for the World Bank Group Energy Sector Strategy

30. IEA (2011) IEA analysis of fossil-fuel subsidies. World Energy Outlook

31. Schellong W (2011) Energy demand analysis and forecast. In: Kini G (ed). Energy Manag. Syst. INTECH Publishers, pp 101-122. https://doi.org/10. $5772 / 21022$

32. Doukas H, Patlitzianas KD, Kagiannas AG, Psarras J (2008) Energy policy making: an old concept or a modern challenge? Energy Sources Part B Econ Plan Policy 3:362-371. https://doi.org/10.1080/15567240701232378

33. Bhattacharyya SC (2011) Understanding and analysing energy demand. Energy economics. Springer, London, London, pp 41-76

34. Edomah N (2019) Governing sustainable industrial energy use: energy transitions in Nigeria's manufacturing sector. J Clean Prod 210:620-629. https://doi.org/10.1016/J.JCLEPRO.2018.11.052

35. Lin B, Ankrah I (2019) On Nigeria's renewable energy program: examining the effectiveness, substitution potential, and the impact on national output. Energy 167:1181-1193. https://doi.org/10.1016/J.ENERGY.2018. 11.031

36. Arowolo W, Blechinger P, Cader C, Perez Y (2019) Seeking workable solutions to the electrification challenge in Nigeria: Minigrid, reverse auctions and institutional adaptation. Energy Strateg Rev 23:114-141. https://doi. org/10.1016/j.esr.2018.12.007

37. Bamisile O, Huang Q, Xu X et al (2020) An approach for sustainable energy planning towards $100 \%$ electrification of Nigeria by 2030. Energy 197:117172. https://doi.org/10.1016/J.ENERGY.2020.117172

38. Edomah N, Foulds C, Jones A (2017) Policy making and energy infrastructure change: a Nigerian case study of energy governance in the electricity sector. Energy Policy 102:476-485. https://doi.org/10.1016/j. enpol.2016.12.053

39. Shove E, Pantzar M, Watson M (2012) The dynamics of social practice: everyday life and how it changes. SAGE Publ. https://doi.org/10.4135/ 9781446250655

40. Shove E, Watson M, Spurling N (2015) Conceptualizing connections: energy demand, infrastructures and social practices. Eur J Soc Theory 18:1-14. https://doi.org/10.1177/1368431015579964

41. Edomah N, Foulds C, Jones A (2016) Energy transitions in Nigeria: the evolution of energy infrastructure provision (1800-2015). Energies 9:484. https://doi.org/10.3390/en9070484

42. World Energy Council (2016) World Energy Resources 2016. World Energy Council; 2016. http://www.worldenergy.org/wp-content/uploads/2013/ 09/Complete_WER_2013_Survey.pdf. Accessed 20 Oct 2019.

43. Edomah N, Nwaubani S (2014) Energy security challenges in developing African mega cities: the Lagos experience. In: Infrasructure, Risk and Resilience: Managing Complexity and Uncertainty in Developing Cities. The Institution of Engineering and Technology, UK, pp 3-12

44. Scott J (2006) Documentary Research [Internet]. Lecture Guide. Available from: http://books.google.dk/books?id=KOlyMwEACAAJ.

45. Lacerda AL (2012) Photographs in archives: the production and meaning of visual records. História, Ciências, Saúde - Manguinhos. Rio de Janeiro

46. National Archives (2017) Document Analysis Worksheets [Internet]. WAshington DC, USA; [cited 2017 Aug9]. Available from: https://www.archives. gov/education/lessons/worksheets
47. Edomah N (2017) Modelling future electricity: rethinking the organizational model of nigeria's electricity sector. IEEE Access 5:27074-27080. https://doi.org/10.1109/ACCESS.2017.2769338

48. Moner-Girona M, Bódis K, Morrissey J et al (2019) Decentralized rural electrification in Kenya: Speeding up universal energy access. Energy Sustain Dev 52:128-146. https://doi.org/10.1016/j.esd.2019.07.009

49. van Gevelt T, Canales Holzeis C, Fennell S et al (2018) Achieving universal energy access and rural development through smart villages. Energy Sustain Dev 43:139-142. https://doi.org/10.1016/j.esd.2018.01.005

50. Surroop D, Bundhoo ZMA, Raghoo P (2019) Waste to energy through biogas to improve energy security and to transform Africa's energy landscape. Curr Opin Green Sustain Chem 18:79-83. https://doi.org/10.1016/j. cogsc.2019.02.010

51. Di Silvestre ML, Favuzza S, Riva Sanseverino E, Zizzo G (2018) How decarbonization, digitalization and decentralization are changing key power infrastructures. Renew Sustain Energy Rev 93:483-498. https://doi.org/10. 1016/j.rser.2018.05.068

52. Monyei CG, Sovacool BK, Brown MA et al (2019) Justice, poverty, and electricity decarbonization. Electr J 32:47-51. https://doi.org/10.1016/j.tej. 2019.01.005

53. Baarsch F, Granadillos JR, Hare W et al (2020) The impact of climate change on incomes and convergence in Africa. World Dev 126:104699. https://doi.org/10.1016/j.worlddev.2019.104699

54. Filho WL, Balogun AL, Ayal DY et al (2018) Strengthening climate change adaptation capacity in Africa- case studies from six major African cities and policy implications. Environ Sci Policy 86:29-37. https://doi.org/10. 1016/j.envsci.2018.05.004

55. Eshun ME, Amoako-Tuffour J (2016) A review of the trends in Ghana's power sector. Energy Sustain Soc 6:1-9. https://doi.org/10.1186/ s13705-016-0075-y

56. Arjun K, Sankaran A, Kumar S, Das M (2020) An endogenous growth approach on the role of energy, human capital, finance and technology in explaining manufacturing value-added: a multi-country analysis. Heliyon. 6(7):e04308

57. Zaharia A, Diaconeasa MC, Brad L et al (2019) Factors influencing energy consumption in the context of sustainable development. Sustain 11:1-28. https://doi.org/10.3390/su11154147

58. Ackah I, Adu F, Opoku Takyi R (2014) On the demand dynamics of electricity in Ghana: Do exogenous non-economic variables count? Int J Energy Econ Policy 4:149-153

59. Edomah N (2018) Deindustrialization and effects of poorly implemented energy policies on sustainable industrial growth. In: Yülek M (ed) Industrial Policy for a sustainable growth. Singapore, Springer Nature Singapore, pp 311-322

60. Edomah N, Foulds C, Malo I (2021) Energy Access and Gender in Nigeria: Policy Brief. Global Sustainability Institute, Cambridge, pp 1-3

61. World Bank Group (2013) Toward a sustainable energy future for all: directions for the world bank group's energy sector.

62. Geels FW (2014) Regime resistance against low-carbon transitions: introducing politics and power into the multi-level perspective. Theory, Cult Soc. https://doi.org/10.1177/0263276414531627

63. Victor D, Heller T (2007) The political economy of power sector reform: the experiences of five major developing countries. Cambridge Univ, Press

64. Prasad S (1993) Steam engine characteristics and theoretical performance. Energy Convbersion Manag 34:1323-1333

65. Li T, Liu Z, Zhang H, Jiang Q (2013) Environmental emissions and energy consumptions assessment of a diesel engine from the life cycle perspective. J Clean Prod 53:7-12. https://doi.org/10.1016/j.jclepro.2013.04.034

66. Lubega WN, Stillwell AS (2019) Analyzing the economic value of thermal power plant cooling water consumption. Water Resour Econ 27:100137. https://doi.org/10.1016/j.wre.2019.01.003

67. Grubert E (2020) Conventional hydroelectricity and the future of energy : Linking national inventory of dams and energy information administration data to facilitate analysis of hydroelectricity. Electr J 33:106692. https://doi.org/10.1016/j.tej.2019.106692

68. Abreu J, Wingartz N, Hardy N (2019) New trends in solar: a comparative study assessing the attitudes towards the adoption of rooftop PV. Energy Policy 128:347-363. https://doi.org/10.1016/j.enpol.2018.12.038

69. Demirel $Y$ (2012) Energy production, conversion, storage, conservation, and coupling. https://doi.org/10.1007/978-1-4471-2372-9 
70. Ibarra-berastegi G, Gonz SJ, Ulazia A et al (2019) Global estimations of wind energy potential considering seasonal air density changes. Energy. https://doi.org/10.1016/j.energy.2019.115938

71. Esfeld M (2003) What are social practices? Indaga Rev Int Ciencias Soc y Humanas 1:19-43

72. Edomah N, Foulds C, Jones A (2017) Influences on energy supply infrastructure: a comparison of different theoretical perspectives. Renew Sustain Energy Rev 79:765-778. https://doi.org/10.1016/j.rser.2017.05.072

73. Warde A (2005) Consumption and theories of practice. J Consum Cult 5:131-153. https://doi.org/10.1177/1469540505053090

74. Edomah N (2013) Optimizing energy consumption in industrial plants through effective energy monitoring \& targeting. Int J Engineeering Technol 3:702-705
75. Shove E (2003) Comfort, Cleanliness, and Convenience. The social organization of normality.Berg Publishers

76. Wood N, Roelich K (2019) Tensions, capabilities, and justice in climate change mitigation of fossil fuels. Energy Res Soc Sci 52:114-122. https:// doi.org/10.1016/j.erss.2019.02.014

77. Coenen L, Hansen T, Glasmeier A, Hassink R (2021) Regional foundations of energy transitions. Cambridge J Reg Econ Soc. https://doi.org/10.1093/ cjres/rsab010

\section{Publisher's Note}

Springer Nature remains neutral with regard to jurisdictional claims in published maps and institutional affiliations.
Ready to submit your research? Choose BMC and benefit from:

- fast, convenient online submission

- thorough peer review by experienced researchers in your field

- rapid publication on acceptance

- support for research data, including large and complex data types

- gold Open Access which fosters wider collaboration and increased citations

- maximum visibility for your research: over $100 \mathrm{M}$ website views per year

At BMC, research is always in progress.

Learn more biomedcentral.com/submissions 